\section{PP-533 滋賀医科大学における陰茎癌の臨床的検討}

\section{滋賀医科大学医学部泌尿器科学}

西川 全海, 水流 輝彦, 牛田 博, 影山 進,

岩城 秀出洙, 上仁 数義, 成田 充弘, 岡本 圭生,

吉貴 達宽, 岡田 裕作

陰茎癌は発生頻度が低く、泌尿器科領域において稀な悪性 腫瘍であり、治療ガイドラインが確立されていないのが現 状である。今回我々は 1978 年から 2006 年の 29 年間に滋賀 医大附属病院泌尿器科において診療を行った陰荎癌 13 症 例の臨床的検討を行った。年齢は 51 歳から 85 歳で、平均 年龄は 63.5 歳であった。病理は 12 例が扁平上皮癌、 1 例が 病状癌であり、臨床病期（UICC2002 年）は、stage 0 が 1 例、 stage I が 1 例、 stage II が 1 例、 stage III が 5 例、 stage IV が 1 例、不明が 4 例であった。最近のリンパ節転移を伴 う進行性陰茎癌の 4 症例（stage II 1 例、stage III 3 例）に 対しては、原発巣の手術治療後に、MTX、CDDP、BLM を併用した化学療法 (MPB 療法) とリンパ節郭清術による 集学的治療を行い、良好な経過を得ている。MPB 療法は原 則 2 コースを行い、画像診断におけるリンパ節腫脤の部位 やMPB 療法の奏功度を考虑し、最終的には術中迅速病理 検查の結果からリンパ節の郭清範囲を決定した。陰菱癌 13 症例の臨床的統計掞よび進行性陰茎癌に対するMPB 療法 を用いた集学的治療の治療成績について、文献的考察を加 えて報告する。

\section{PP-534 精巣微小石灰化症例の検討一第 2 報一}

聖マリアンナ医科大学泌尿器科"), 聖マリアンナ医科大学 小児外科2，聖マリアンナ医科大学放射線科 ${ }^{3)}$

力石 辰也 ${ }^{11}$, 中野 透1), 岩本 晃明 ${ }^{11}$, 高橋 剛 ${ }^{12}$,

北川 博昭2, 过本 文雄 $\left.{ }^{3}\right)$

【目的】精巣微小石灰化（ML）を検討した。【対象】当院に て精巣超音波検査を行った 15 歳以下の小児 201 例と成人 246 例を対象とした。方法】超音波画像は 1 人の放射線科 医が微小石灰化の有無とその type を判定し、両側・5 個以 上びまん性に ML を認める classic type（C type）と、両側 または片㑡で 5 個未満の MLを認める limited type（L type）に分類した。微小石灰化を有する率を、全症例およ び超音波検查の適応別に検討した。結果】小児例における ML は、全 201 例 中 C type が 7 例 $3.5 \% 、$ L type が 17 例 $8.5 \%$ に認められた。成人例では、全 246 例中 C type が 20 例 $8.3 \% 、$ L type が $11.2 \%$ に認められた。疾患別では小児の 停留精巣では C type 123 例中 3 例 $2.4 \%$ に、 L type を 14 例 $11.1 \%$ に認めたが、精巣水瘤では 24 例中に ML は 1 例も認めなかった。成人では精巣腫瘍において C typeを 20 例中 6 例 $30 \%$ に、L type を 8 例 $40 \%$ と高率に認めた。 不妊症の 128 例では、C type を 7 例 $5.5 \%$ に、L type 24 例 $18.8 \%$ KL を認めた。結語】小児・成人ともにL type がやや多く、停留精巣・不妊・精巣腫瘍で MLを高率に認 めた。

\section{PP-535}

CD90（Thy-1）を用いたヒト精子幹細胞

human spermatogonial stem cells （SSCs）の分離及び培養の試み

\section{東邦大学医学部泌尿器科学 \\ 小林 秀行, 永尾 光一, 片岡 和義, 永田 雅人, 山辺史人, 高杉 啓一郎, 大平 直, 中島 耕一,}

栗田 稔, 原 啓, 三浦 一陽, 石井 延久

【目的】精巣に扔ける Spermatogonial stem cells (SSCs) の自 己複製または分化は、正常な造精機能を維持するために繳密 に調節されている。しかし、その機構は、不明な点が多い。す でに、マウスにおいては、Thy-1 を用いたマウス Spermatogonial stem cells (SSCs)の分離及び serum-free 培盖液に関して は、すでに確立している。しかし、ヒトに関しては、未だ明ら かではない。我々は、ヒト精巣組織より、Thy-1を用いたヒト Spermatogonial stem cells (SSCs) の分離が可能であるか検討 を行なった【方法】ヒト組織を用いるにあたってインフォー ムドコンセントを得て実験に使用した。マウス Spermatogonial stem cells（SSCs）の表面に発現している Thy-1を Magnet Activated Cell Sorting (MACS) を用いて、Thy-1 陽性細 胞を分離する方法と同様な方法で、ヒト精巣組織より分離を 試みた。また、分離された細胞を RT-PCR，および免疫染色に て、Thy-1の発現の確認を行なった。結論】MACSを用いた 分離方法扔よび結果について、総会にて発表予定である。ヒト Spermatogonial stem cells (SSCs) の研究は、男性不娃の解明 及び治療のブレイクスルーにつながると思われる。

\section{PP-536}

\section{トロフィニン結合ペプチドの精子運動能 改善効果}

弘前大学医学部泌尿器科学"1, 杏林大学医学部産婦人 科2), バーナム研究所 ${ }^{3)}$

畠山 真吾 ${ }^{1}$, 岡本 互希子(1), 今井 篤1), 石村 大史 ${ }^{1)}$,

萩沢 茂1), 米山 高弘”, 古家 环也 ${ }^{11}$, 大和 隆 ${ }^{11}$,

大山 力 ${ }^{11}$, 杉原一廣2), 福田 道子 ${ }^{3)}$

くはじめに>着床関連接着分子トロフィニンは子宮内膜上で夕 ステイン、ビスティンと複合体を形成しているが、マウスの精子 にも強く発現していることが知られている。精子鞭毛ではダイニ ンが精子の運動と男性不妊に関与するタンパク質 (Tctex1) と結 合し、さらにタステインと結合しており、この複合体が精子の運 動能を調整している可能性が高いと考えられる。そこで、トロ フィニンを介したシグナル伝達の存在と精子運動能への関与を 明らかにするための検討を行った。く対象と方法＞抗トロフィニ ンモノクローナル抗体の代替として Phage Display 法でクロー ニングしたトロフィニン結合ペプチド : GWRQ を用いて以下の 検討を行った。 1. HT-H cell におけるトロフィニンを介したシグ ナル伝達に関する検討。2.GWRQペプチドによるヒト精子運動 能の変化。<結果 $>E G F$ とトロフィニンによりチロシンリン酸 化が誘導され細胞增殖が惹起された。インフォムドコンセントの 得られた健常人からの精子では運動率の低い 3 例の精子で平均 $52 \%$ 運動率の改善が認められた。くとめ>トロフィニンはシ グナル伝達に関与することが示唆され、 GWRQペプチド添加に よりマウスおよびヒト精子運動能の充進が観察された。 